\title{
AN APPROACH ON GLOBALIZATION FROM A PROCESS POINT OF VIEW
}

\author{
Vlad Polearus, post-graduate ASEM
}

\begin{abstract}
The globalization process hasn't been triggered randomly or spontaneously. It acted in accordance with certain prior tendencies. Nevertheless it appeared as a response to crises in economic, energetic, financial, currency, raw material and alimentary fields from the end of the 60s and the beginning of the 70s which shook the world's economy. It began to define itself as a strategic instrument for big companies and banks to ensure their profitability regardless of the superficial or deep changes which have occurred in different economies where they have invested their capitals.
\end{abstract}

The globalization process hasn't been triggered randomly or spontaneously. It acted in accordance with certain prior tendencies. Nevertheless it appeared as a response to crises in economic, energetic, financial, currency, raw material and alimentary fields from the end of the 60 s and the beginning of the 70s which shook the world's economy. It began to define itself as a strategic instrument for big companies and banks to ensure their profitability regardless of the superficial or deep changes which have occurred in different economies where they have invested their capitals.

Henry Kissinger, American Secretary of State during President Richard Nixon's mandate, in January 2005 mentioned that "the rapid development of Chinese economy and the growth of China's power as a state are favorable to peace and world prosperity... its economical development presented many challenges, but these concern the international competition and can be solved based on the competition's rules."1

"Protests against globalization... are early warnings, outlining the potentially political importance of those who consider themselves at the mercy of some which they cannot influence" mentions Henry Kissinger ${ }^{2}$.

The approach on globalization as a process implies the analysis of entries, existing processes and exits, which become entries for other processes, having a century's old evolution and continuity.

Our vision concerning process based globalization is presented in fig. 1 .

\footnotetext{
${ }^{1}$ www.globalizarea.com/globalizare-stiri-china.htm

${ }^{2}$ Dinu Marin „Globalizarea şi aproximările ei”, Economic Publishing House, Bucharest, 2004, 334 pages., pag.170
} 


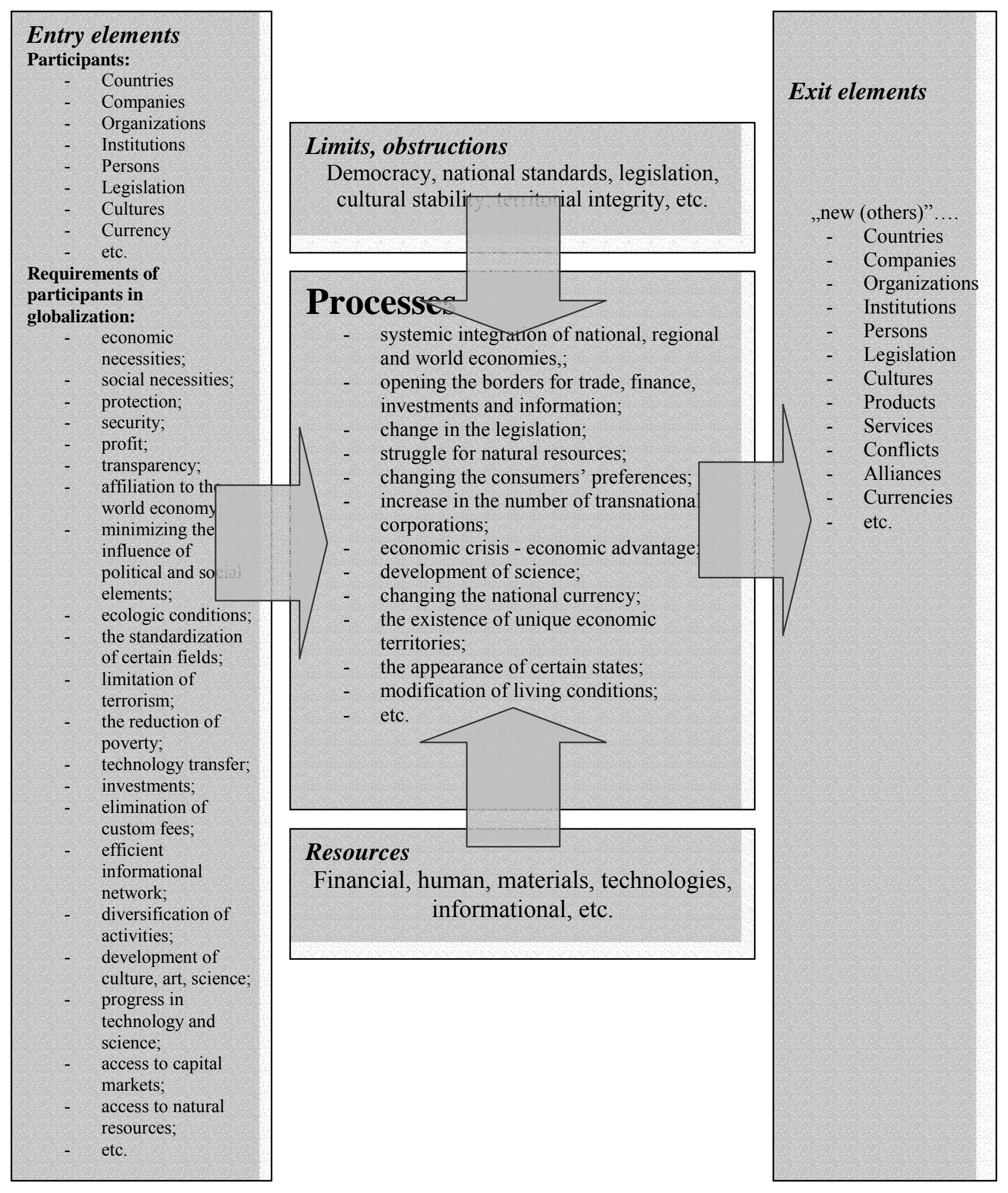

Source: elaborated by the author Fig. 1 Process based globalization approach 
Globalization represents the stage, at the end of the $20^{\text {th }}$ century, of the secular process of the internationalization of economies and economic activities, as a result of the modifications occurred in the internal and international economical structures. made of: ${ }^{3}$

The generating elements and features of this stage are assembled in a complex

* Substantial modifications in the productive structures, marked by a high rate of international expansion of production, concentrated and controlled by transnational corporations;

* The international production has increased within the production's ensemble;

* Visible changes in the technological structures when moving from a rigid mass production to a flexible one, automatic and with robots, capable to ensure both the increase of the productivity and the superior quality of products, adequate to the consumers' varied requirements;

* The multiplication and diversification of the international commercial exchanges, performed nowadays based on universally established rules.

* Major changes regarding the capital and financial structures. By the integration of the international financial markets, by the important increase of their volume and the involvement of the transnational banks in operations with essential influence upon the development of certain countries, a strengthening of the capitals and their domination, the financial one, took place.

* The intensification of the investment flow abroad, especially the direct one.

* The establishment and extension of certain wide fast telecommunication and transport networks which facilitate the economical relations between all locations and economies of the world, as well as the communication and individual and business travels.

* The establishment, in developed and non-developed areas, of certain economies with different integration levels of the markets and goods, services, capital and labor force movement.

* The establishment of a world economy and its functioning within the national economy.

* The extension of the exchange economy up to the world economy level, due to the elimination of the economy administration and management system by countries with excommunist, dictatorial regimes and the involvement of these economies in the transition process towards a modern market economy.

* The adoption of certain economic policies and liberal orientation models in different countries, especially influenced by international financial bodies.

* The multiplication and increase in the interdependence between national economic bodies, taking into consideration their increase. This element leads to, on one hand, the intensification of the mutual exchanges and, on the other hand, to the increase of the vulnerability of the entire economies network and its links, the disturbances and unbalance which appear in one area or another.

* The creation of a conglomerate of problems at a global level, connected one with the other, made of:

- high demographic increase;

- dangerous degradation, sometimes irreversible, of certain ecosystems and environment elements, as a result of the pollution and destructive actions of men;

- the improper and unfair division of resources, their control and consumption, as well as the individual consumption, between rich and poor countries;

\footnotetext{
${ }^{3}$ POPESCU IRINA ALINA, Air transport in the context of the world's economy globalization, doctoral dissertation, Bucharest, 2006, page 35 .
} 
- $\quad$ endemic poverty suffered by over $1 / 5$ from the globe's population;

- unemployment and underestimation of the creative force of men;

- transforming certain aspects at national level into international disasters like drug traffic, organized crime, corruption, illegal sources money laundry, with serious economical and social implications;

- the deterioration of the situation of certain marginal economies belonging to countries in development and the appearance of the ,grey areas" with a lot of interferences, of the countries in transition towards a capitalism with dependent development.

Therefore we may say that the world's economy, at this stage of globalization, is characterized by larger and deeper international flows of commerce, finance, capital, technological transfers, information that interfere on an integrated and unique world market.

\section{Bibliography:}

${ }^{1}$ www.globalizarea.com/globalizare-stiri-china.htm

2 Dinu Marin „Globalizarea şi aproximările ei”, Economic Publishing House, Bucharest, 2004, 334 pages., pag. 170

${ }^{3}$ POPESCU IRINA ALINA, Air transport in the context of the world's economy globalization, doctoral dissertation, Bucharest, 2006, page 35. 